\title{
Recent advances in understanding and managing
}

\section{postoperative respiratory problems [version 1; peer review: 2}

\section{approved]}

\author{
Matthias Eikermann1, Peter Santer (D1), Satya-Krishna Ramachandran1, \\ Jaideep Pandit ${ }^{2}$ \\ ${ }^{1}$ Department of Anesthesia, Critical Care and Pain Medicine, Beth Israel Deaconess Medical Center, Harvard Medical School, Boston, \\ USA \\ ${ }^{2}$ Nuffield Department of Anaesthetics, Oxford University Hospitals NHS Foundation Trust, Oxford, UK
}

V1 First published: 18 Feb 2019, 8(F1000 Faculty Rev):197

https://doi.org/10.12688/f1000research.16687.1

Latest published: 18 Feb 2019, 8(F1000 Faculty Rev):197

https://doi.org/10.12688/f1000research.16687.1

\begin{abstract}
Postoperative respiratory complications increase healthcare utilization (e.g. hospital length of stay, unplanned admission to intensive care or high-dependency units, and hospital readmission), mortality, and adverse discharge to a nursing home. Furthermore, they are associated with significant costs. Center-specific treatment guidelines may reduce risks and can be guided by a local champion with multidisciplinary involvement. Patients should be risk-stratified before surgery and offered anesthetic choices (such as regional anesthesia). It is established that laparoscopic surgery improves respiratory outcomes over open surgery but requires tailored anesthesia/ventilation strategies (positive end-expiratory pressure utilization and low inflation pressure). Interventions to optimize treatment include judicious use of intensive care, moderately restrictive fluid therapy, and appropriate neuromuscular blockade with adequate reversal. Patients' ventilatory drive should be kept within a normal range wherever possible. High-dose opioids should be avoided, while volatile anesthetics appear to be lung protective. Tracheal extubation should occur in the reverse Trendelenburg position, and postoperative continuous positive airway pressure helps prevent airway collapse. In combination, all of these interventions facilitate early mobilization.
\end{abstract}

Keywords

respiration, hypoxia, hypercapnia, ventilation

\section{Open Peer Review}

Approval Status

1

2

version 1

$18 \mathrm{Feb} 2019$

Faculty Reviews are review articles written by the prestigious Members of Faculty Opinions. The articles are commissioned and peer reviewed before publication to ensure that the final, published version is comprehensive and accessible. The reviewers who approved the final version are listed with their names and affiliations.

1. Albert Dahan ID, Leiden University Medical Center, Leiden, The Netherlands

2. Mehmet Haberal, Baskent University Faculty of Medicine, Ankara, Turkey

Any comments on the article can be found at the end of the article. 
Corresponding author: Jaideep Pandit (jaideep.pandit@sjc.ox.ac.uk)

Author roles: Eikermann M: Conceptualization, Investigation, Resources, Validation, Writing - Review \& Editing; Santer P: Data Curation, Validation, Writing - Review \& Editing; Ramachandran SK: Project Administration, Resources, Writing - Review \& Editing; Pandit J: Conceptualization, Writing - Original Draft Preparation, Writing - Review \& Editing

Competing interests: ME has received grants from Merck, and holds a patent for a new drug to reverse neuromuscular blocking agents and fentanyl. SR has received honoraria from Fresenius Kabi and is on their scientific advisory board. JP and PS have no competing interests.

Grant information: This work was supported by an unrestricted grant from Jeff and Judy Buzen to develop personalized perioperative care to ME.

The funders had no role in study design, data collection and analysis, decision to publish, or preparation of the manuscript.

Copyright: @ 2019 Eikermann $\mathrm{M}$ et al. This is an open access article distributed under the terms of the Creative Commons Attribution License, which permits unrestricted use, distribution, and reproduction in any medium, provided the original work is properly cited.

How to cite this article: Eikermann M, Santer $\mathrm{P}$, Ramachandran SK and Pandit J. Recent advances in understanding and managing postoperative respiratory problems [version 1; peer review: 2 approved] F1000Research 2019, 8(F1000 Faculty Rev):197 https://doi.org/10.12688/f1000research.16687.1

First published: 18 Feb 2019, 8(F1000 Faculty Rev):197 https://doi.org/10.12688/f1000research.16687.1 


\section{Introduction}

Postoperative respiratory complications commonly occur, with an incidence of up to approximately $10 \%$ in general surgery ${ }^{1-4}$ (even higher with thoracic surgery ${ }^{5}$ ). Complications include postextubation hypoxemia, reintubation, acute respiratory failure, pulmonary edema, pneumonia, and atelectasis. These increase hospital length of stay, unplanned ICU admissions, hospital readmissions, mortality, and costs ${ }^{6-11}$. For example, respiratory failure after abdominal surgery can increase 30-day mortality 10 -fold ${ }^{6}$.

\section{Pathophysiology}

Pathologically, we can characterize respiratory complications as being due to respiratory muscle dysfunction or as a primary airway disease. The latter can in turn be subdivided into upper airway-related complications, such as reintubation of an obstructive sleep apnea (OSA) patient, or pulmonary complications, such as pulmonary edema.

Both respiratory muscle dysfunction and airway disease can develop as a consequence of an imbalance in ventilatory drive. Both increases and decreases in ventilatory drive are potentially harmful and may, for example, increase the risk of aspiration by negatively affecting the interaction between breathing and swallowing (Figure 1). Sedation due to opioid and anxiolytic therapy commonly leads to upper airway dysfunction, resulting in insufficient respiration (hypopnea/apnea), but also affects the breathing-swallowing coordination and pharyngeal muscle strength, both of which contribute to pharyngeal dysfunction and increased risk of aspiration ${ }^{12}$. In turn, an increase in respiratory drive (e.g. during hypercapnic respiratory failure) can lead to high transpulmonary pressure during inspiration, which increases lung stress. Supplementation of inhaled carbon dioxide was shown to reverse upper airway collapsibility induced by propofol $^{13}$, but excessive hypercapnia increases the likelihood of pathological swallowing ${ }^{14}$. Thus, perioperative physicians need to balance their interventions to keep ventilatory drive within normal limits. Upper airway collapse can lead to desaturation, atelectasis, and respiratory failure. Patency of the upper airway depends on competing dilating versus collapsing forces ${ }^{15,16}$. The former includes the pharyngeal dilator muscles (genioglossus and tensor palatini) and caudal traction on the airway from lung expansion (which can be improved by positive end-expiratory pressure [PEEP]). Sedatives, opioids, or even delirium can decrease airway dilator muscle tone. Dilating forces are influenced by atelectasis or the inevitable supine position of surgery. In contrast, collapsing forces include external pressure from surrounding soft tissue, which is increased in the presence of edema, obesity, blood clots, and tumors or in the supine position.

Remarkably, perhaps, significant postoperative pulmonary edema is reported in up to $1-2 \%$ of patients ${ }^{9}$, and causes include negative pressure pulmonary edema, fluid shifts, and, rarely, neurogenic edema in acute hypertension or after cerebral injury ${ }^{17}$.

More common than edema is atelectasis, and its pathophysiology starts minutes after induction ${ }^{18}$. A reduced regional transpulmonary pressure in dependent lung areas is accentuated by inflam-

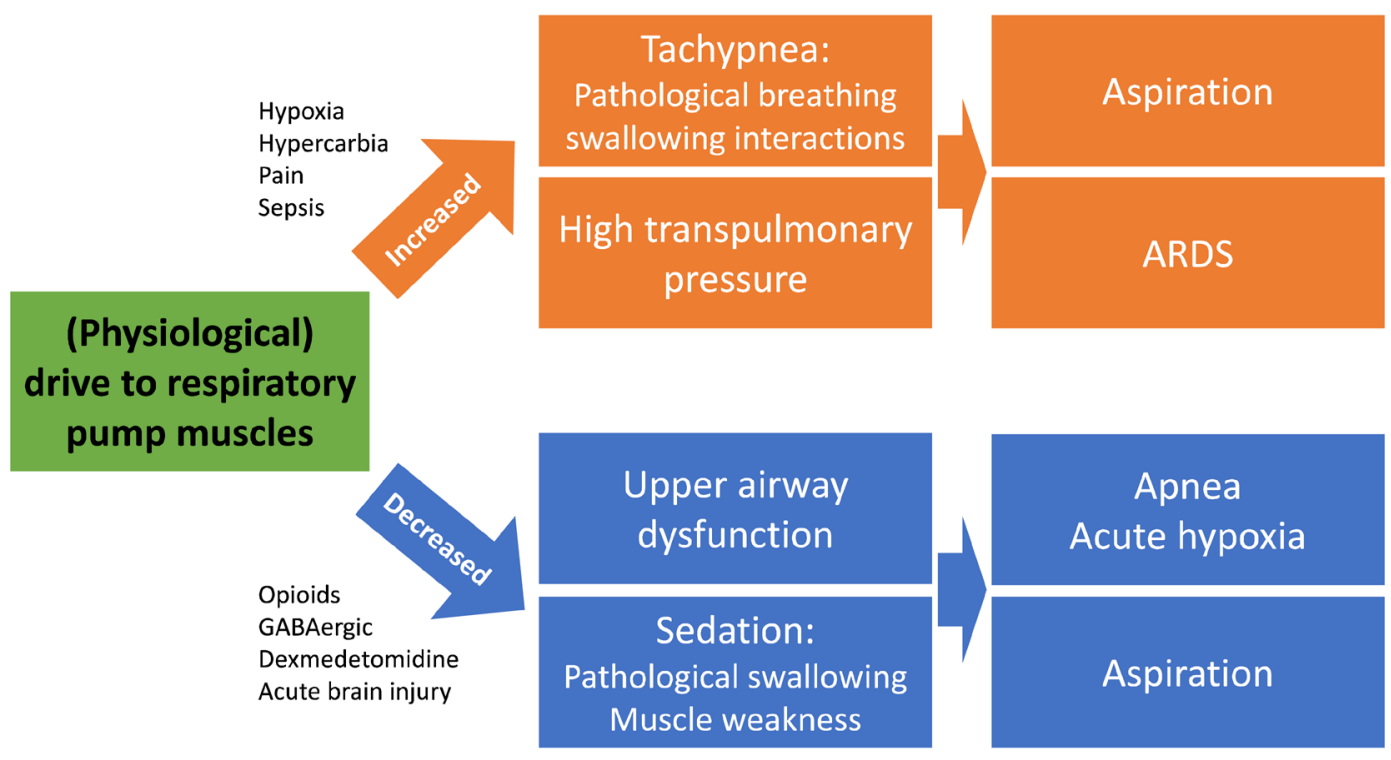

Figure 1. Effects of respiratory drive on perioperative respiratory complication risk. Changes in respiratory drive play a key role in the development of postoperative respiratory complications. Both increases and decreases in respiratory drive are potentially harmful and can affect the risk of aspiration. In addition, an increase in respiratory drive, for example during hypercapnic respiratory failure, can lead to high transpulmonary pressure during inspiration, which increases lung stress. Sedation commonly leads to upper airway dysfunction, resulting in insufficient respiration (hypopnea/apnea) but also affects the breathing-swallowing coordination and pharyngeal muscle strength, both of which contribute to pharyngeal dysfunction and increased risk of aspiration ${ }^{12}$. Supplementation of inhaled carbon dioxide was shown to reverse upper airway collapsibility induced by propofol ${ }^{13}$, but excessive hypercapnia increases the likelihood of pathological swallowing ${ }^{14}$. Thus, perioperative physicians need to balance their interventions to keep ventilator drive within normal limits. ARDS, acute respiratory distress syndrome. 
mation induced by surgery, bacterial translocation, chest wall restriction, and cephalad diaphragm displacement by surgical retraction. This extends postoperatively, such that a restrictive pattern worsens respiratory mechanics and gas exchange. Pain, high inflation driving pressures, and inflammation all contribute.

Ventilator-induced lung injury has multiple causes. In addition to barotrauma, reduced lung compliance in unrecruited areas causes overinflation of aerated lung tissue in nondependent areas with subsequent "volutrauma". Cyclical effects lead to "atelectotrauma". As mentioned above, the release of local proinflammatory mediators also contributes to lung injury "biotrauma"19,20.

\section{Recommendations for patient management}

Modifiable perioperative factors in patient management are shown in Table 1. All the aforementioned pathophysiological processes make the optimization of ventilation as a protective strategy logical. What is really important, though, is preoperative screening and patient selection. The Score for Prediction of Postoperative Respiratory Complications (SPORC) is useful in this regard, as it relates the probability of re-intubation to ASA score, emergency surgery, heart failure, and pulmonary disease ${ }^{21}$.
However, SPORC does not include factors such as smoking. Smoking is associated with increased risk of postoperative respiratory complications, and smoking cessation before surgery has been shown to decrease adverse respiratory events ${ }^{22,23}$.

The method of anesthesia induction can be preventative for postoperative complications. Keeping a patient as upright as possible during induction may help optimize mask ventilation and also help during extubation. This approach may prevent atelectasis, which may be especially important in patients with OSA $\mathrm{OS}^{24,25}$.

After intubation, lung-protective mechanical ventilation aims to maintain lung recruitment by keeping transpulmonary pressures within the optimal (linear) part of the local pressure-volume curve. Results from ICU patients suggest reduced morbidity and mortality in the setting of acute lung injury ${ }^{26,27}$. Typically, a PEEP of at least $5 \mathrm{~cm} \mathrm{H}_{2} \mathrm{O}$ and a median plateau pressure of $16 \mathrm{~cm} \mathrm{H}_{2} \mathrm{O}$ appear to be the most beneficial ${ }^{28}$. However, protective effects of PEEP may be very procedure specific, as a PEEP of approximately $5 \mathrm{~cm} \mathrm{H}_{2} \mathrm{O}$ in major abdominal surgery is beneficial, whereas this is not matched by effects of the same level of PEEP in neurosurgery ${ }^{29}$. Also, PEEP must be patient

Table 1. Perioperative factors associated with postoperative respiratory complications (PRCs).

\begin{tabular}{|c|c|c|c|c|}
\hline Factor & Main findings & Definition of PRC & Cohort & Reference \\
\hline \multicolumn{5}{|c|}{ Case management } \\
\hline $\begin{array}{l}\text { Open vs. } \\
\text { laparoscopic } \\
\text { surgery }\end{array}$ & Laparoscopy reduced PRCs & $\begin{array}{l}\text { Pulmonary infection, ARDS, } \\
\text { symptomatic pleural effusion, } \\
\text { respiratory insufficiency, } \\
\text { pulmonary embolism }\end{array}$ & $\begin{array}{l}1,214 \text { patients undergoing } \\
\text { major hepatectomy }\end{array}$ & Fuks et $a l^{30}$ \\
\hline $\begin{array}{l}\text { General vs. } \\
\text { regional } \\
\text { anesthesia }\end{array}$ & $\begin{array}{l}\text { Neuraxial anesthesia reduced } \\
\text { mortality and PRCs }\end{array}$ & $\begin{array}{l}\text { Pulmonary embolism, pneumonia, } \\
\text { respiratory depression }\end{array}$ & $\begin{array}{l}\text { 9,559 patients undergoing } \\
\text { surgery with or without } \\
\text { epidural or spinal anesthesia } \\
\text { (systematic review) }\end{array}$ & Rodgers et al. ${ }^{31}$ \\
\hline \multicolumn{5}{|l|}{ Ventilation } \\
\hline $\begin{array}{l}\text { Protective } \\
\text { ventilation }\end{array}$ & $\begin{array}{l}\text { Intraoperative protective } \\
\text { ventilation was associated with } \\
\text { lower risk of PRCs }\end{array}$ & $\begin{array}{l}\text { Respiratory failure, reintubation, } \\
\text { pulmonary edema, pneumonia }\end{array}$ & $\begin{array}{l}69,265 \text { non-cardiac surgical } \\
\text { patients undergoing general } \\
\text { anesthesia with endotracheal } \\
\text { intubation }\end{array}$ & Ladha et al. ${ }^{28}$ \\
\hline $\begin{array}{l}\text { Case- } \\
\text { specific } \\
\text { PEEP }\end{array}$ & $\begin{array}{l}\text { Reduced risk of PRCs and } \\
\text { hospital length of stay with } \\
\text { PEEP } \geq 5 \mathrm{~cm} \mathrm{H}_{2} \mathrm{O} \text { in abdominal } \\
\text { surgical, but not craniotomy, } \\
\text { patients }\end{array}$ & $\begin{array}{l}\text { Respiratory failure, reintubation, } \\
\text { pulmonary edema, pneumonia }\end{array}$ & $\begin{array}{l}5,915 \text { major abdominal } \\
\text { surgical patients and } 5,063 \\
\text { craniotomy patients }\end{array}$ & de Jong et al. ${ }^{29}$ \\
\hline $\mathrm{FiO}_{2}$ & $\begin{array}{l}\text { High intraoperative } \mathrm{FiO}_{2} \text { was } \\
\text { dose-dependently associated } \\
\text { with PRCs and mortality }\end{array}$ & $\begin{array}{l}\text { Respiratory failure, reintubation, } \\
\text { pulmonary edema, pneumonia }\end{array}$ & $\begin{array}{l}\text { 73,922 mechanically ventilated } \\
\text { non-cardiac surgical patients }\end{array}$ & Staehr-Rye et al. ${ }^{32}$ \\
\hline \multicolumn{5}{|c|}{ Pharmacological factors } \\
\hline $\begin{array}{l}\text { Volatile } \\
\text { anesthetics }\end{array}$ & $\begin{array}{l}\text { Higher doses of inhalational } \\
\text { anesthetics were associated } \\
\text { with lower risk of PRCs, reduced } \\
\text { mortality, and reduced costs }\end{array}$ & $\begin{array}{l}\text { Respiratory failure, reintubation, } \\
\text { pulmonary edema, pneumonia }\end{array}$ & $\begin{array}{l}124,497 \text { non-cardiac surgical } \\
\text { patients undergoing general } \\
\text { anesthesia with endotracheal } \\
\text { intubation }\end{array}$ & Grabitz et al. ${ }^{33}$ \\
\hline
\end{tabular}




\begin{tabular}{|c|c|c|c|c|}
\hline Factor & Main findings & Definition of PRC & Cohort & Reference \\
\hline \multirow[t]{4}{*}{ NMBAs } & $\begin{array}{l}\text { Postoperative residual } \\
\text { block (TOF ratio <0.7) after } \\
\text { pancuronium administration was } \\
\text { a risk factor for PRCs }\end{array}$ & $\begin{array}{l}\text { Pneumonic infiltrations or } \\
\text { atelectasis on chest X-ray }\end{array}$ & $\begin{array}{l}691 \text { patients undergoing } \\
\text { abdominal, orthopedic, or } \\
\text { gynecological surgery under } \\
\text { general anesthesia }\end{array}$ & Berg et al. ${ }^{34}$ \\
\hline & $\begin{array}{l}\text { Intermediate-acting NMBA use } \\
\text { was associated with increased } \\
\text { risk of PRCs }\end{array}$ & $\begin{array}{l}\mathrm{SpO}_{2}<90 \% \text { with a decrease after } \\
\text { extubation of }>3 \% \text {, reintubation }\end{array}$ & $\begin{array}{l}18,579 \text { patients undergoing } \\
\text { surgical anesthesia with NMBA } \\
\text { use and } 18,579 \text { matched } \\
\text { reference patients }\end{array}$ & $\begin{array}{l}\text { Grosse-Sundrup } \\
\text { et al. }{ }^{35}\end{array}$ \\
\hline & $\begin{array}{l}\text { NMBA use (and neostigmine } \\
\text { reversal) was dose-dependently } \\
\text { associated with PRCs }\end{array}$ & $\begin{array}{l}\text { Respiratory failure, reintubation, } \\
\text { pulmonary edema, pneumonia }\end{array}$ & $\begin{array}{l}48,499 \text { non-cardiac surgical } \\
\text { cases with NMBA use }\end{array}$ & McLean et al. ${ }^{36}$ \\
\hline & $\begin{array}{l}\text { NMBA use was associated with } \\
\text { increased risk of PRCs }\end{array}$ & $\begin{array}{l}\text { Respiratory failure, pulmonary } \\
\text { infection, pulmonary infiltrates, } \\
\text { atelectasis, aspiration } \\
\text { pneumonitis, bronchospasm, } \\
\text { pulmonary edema }\end{array}$ & $\begin{array}{l}22,803 \text { non-cardiac surgical } \\
\text { patients undergoing general } \\
\text { anesthesia }\end{array}$ & Kirmeier et al. ${ }^{37}$ \\
\hline \multirow[t]{2}{*}{$\begin{array}{l}\text { Fluid } \\
\text { management }\end{array}$} & $\begin{array}{l}\text { Liberal fluid administration was } \\
\text { associated with PRCs }\end{array}$ & $\begin{array}{l}\text { Respiratory failure, reintubation, } \\
\text { pulmonary edema, pneumonia } \\
\text { (secondary outcome) }\end{array}$ & $\begin{array}{l}92,094 \text { non-cardiac surgical } \\
\text { patients undergoing general } \\
\text { anesthesia with endotracheal } \\
\text { intubation }\end{array}$ & Shin et al. ${ }^{38}$ \\
\hline & $\begin{array}{l}\text { Liberal fluid administration had } \\
\text { a higher risk of pneumonia and } \\
\text { pulmonary edema; goal-directed } \\
\text { therapy had a lower risk of } \\
\text { pneumonia }\end{array}$ & $\begin{array}{l}\text { Respiratory failure, pulmonary } \\
\text { edema, pneumonia, and pleural } \\
\text { effusion (secondary outcome) }\end{array}$ & $\begin{array}{l}\text { 5,021 surgical patients } \\
\text { enrolled in } 35 \text { RCTs (meta- } \\
\text { analysis) }\end{array}$ & Corcoran et al. ${ }^{39}$ \\
\hline \multirow[t]{3}{*}{ Opioids } & $\begin{array}{l}\text { High intraoperative opioid dose } \\
\text { was associated with increased } \\
\text { readmission rate but not PRCs }\end{array}$ & $\begin{array}{l}\text { Respiratory failure, reintubation, } \\
\text { pulmonary edema, pneumonia } \\
\text { (secondary outcome) }\end{array}$ & $\begin{array}{l}74,748 \text { surgical patients } \\
\text { undergoing general anesthesia }\end{array}$ & Grabitz et al. ${ }^{40}$ \\
\hline & $\begin{array}{l}\text { Most events occurred within } 24 \\
\text { hours after surgery and were } \\
\text { preventable in most cases }\end{array}$ & Respiratory depression & 357 acute pain claims & Lee et al. ${ }^{41}$ \\
\hline & $\begin{array}{l}\text { Opioids and sedatives are } \\
\text { independent and additive } \\
\text { predictors of the outcome }\end{array}$ & $\begin{array}{l}\text { Cardiopulmonary and respiratory } \\
\text { arrest }\end{array}$ & $\begin{array}{l}6,771,882 \text { surgical inpatient } \\
\text { discharges }\end{array}$ & Izrailtyan et al. ${ }^{42}$ \\
\hline
\end{tabular}

ARDS, acute respiratory distress syndrome; $\mathrm{FiO}_{2}$, fraction of inspired oxygen; NMBA, neuromuscular blocking agent; PEEP, positive end-expiratory pressure; $\mathrm{SpO}_{2}$, peripheral capillary oxygen saturation; $\mathrm{RCT}$, randomized controlled trial; TOF, train of four.

specific: those with poor chest wall compliance need higher levels of $\mathrm{PEEP}^{43}$. Although high $\mathrm{FiO}_{2}$ is used to maintain oxygenation, it may also worsen pulmonary function, probably by promoting atelectasis $^{32}$.

Interestingly, it has been found that an increased average minimum alveolar concentration of volatile anesthetics, including nitrous oxide, improves 30-day mortality and the risk of pulmonary complications ${ }^{33}$. The adverse influence of neuromuscular blocking agents (NMBAs) is now well established, especially when associated with inadequate reversal ${ }^{34-37,44,45}$. Monitoring of NMBAs along with reversal guided by neuromuscular transmission is now mandatory according to minimum monitoring guidelines in the $\mathrm{UK}^{46}$. The choice of reversal agent remains controversial; while sugammadex was shown to reduce the incidence of postoperative residual paralysis compared with neostigmine in one randomized controlled trial ${ }^{47}$, a recent multicenter observational study (POPULAR trial) found no association between the reversal agent used and postoperative respiratory complications ${ }^{37}$.
With regard to fluid administration, it is the most-restrictive and the most-liberal strategies that have been associated with respiratory complications, whereas moderate regimens appear to be optimal $^{38,39,48}$. Pain is an adverse factor for respiratory complications, but very high doses of opioids are also potentially harm$\mathrm{ful}^{40}$. Neuraxial blockade may reduce postoperative morbidity and mortality in subpopulations $\mathrm{s}^{31,49}$, and laparoscopic surgery, which may contribute to better analgesia, further appears beneficial ${ }^{30}$. Good pain relief also promotes early mobilization, which shortens patients' length of $\operatorname{stay}^{50}$. Monitoring is important in the detection of early signs of respiratory complications and the decision to admit and observe a patient in the ICU as opposed to the PACU ${ }^{51}$.

\section{Conclusions}

There is a considerable literature base supporting the individual results highlighted above. What is emerging is the need for the development and implementation of center-specific guidelines, based on algorithms, coupled with key performance indicators developed by multidisciplinary teams (Figure 2). 


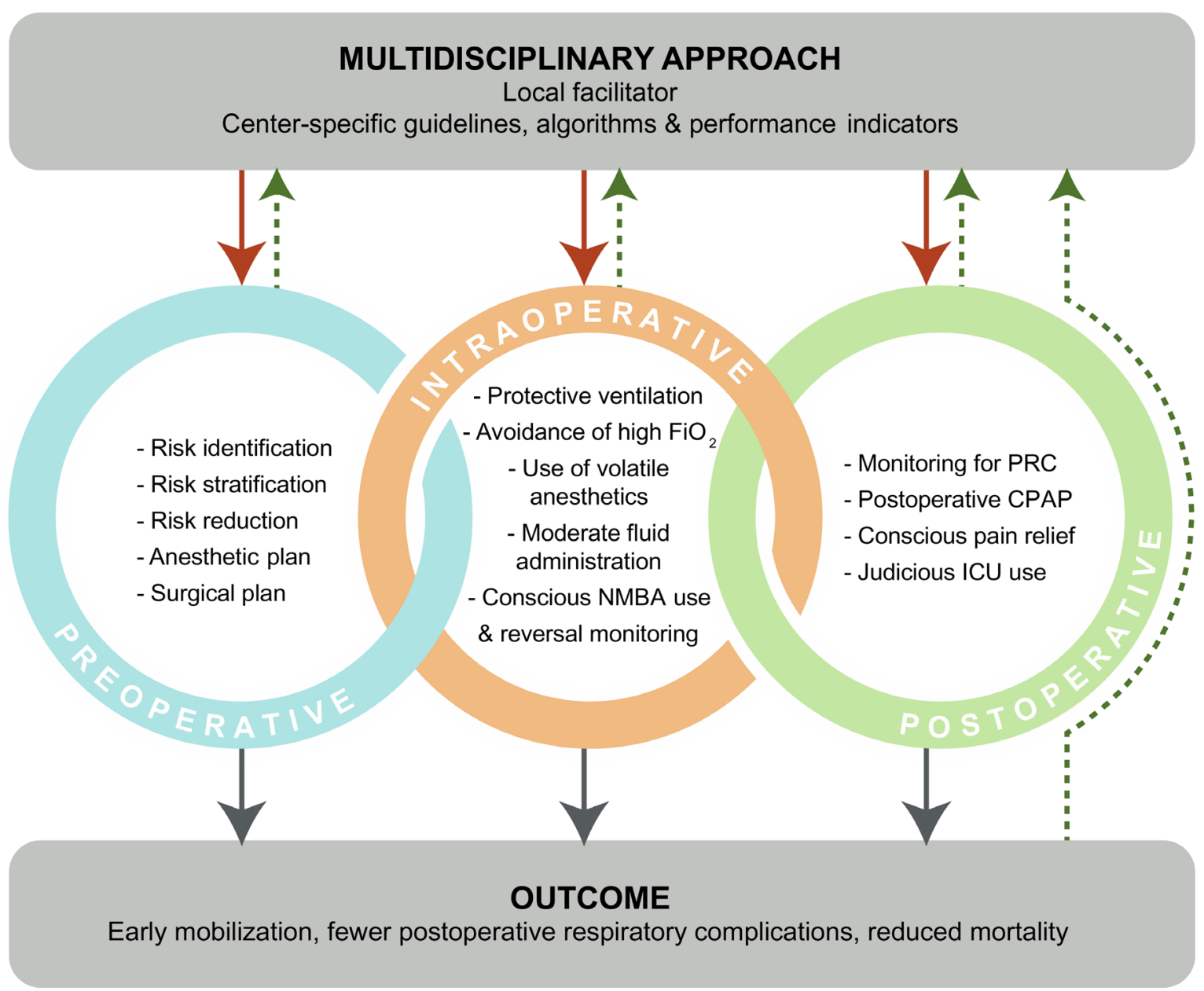

Figure 2. Integration of multilevel guidelines for the prevention of postoperative respiratory complications (PRCs). In a multidisciplinary approach, center-specific guidelines, algorithms, and performance indicators should be developed. Their implementation (red solid arrows) can be facilitated by a local "champion". Factors concerning the preoperative, intraoperative, and postoperative period need to be addressed, as each can have an impact on outcomes. Periodic review and assessment of processes and outcomes (green dotted arrows) will ensure continuous improvement. CPAP, continuous positive airway pressure; FiO2, fraction of inspired oxygen; ICU, intensive care unit; NMBA, neuromuscular blocking agent.

This can form the basis of a continuous quality improvement program. An important driver in achieving this goal is a local champion or "facilitator", who can lead the integration of the needed processes.

\section{Grant information}

This work was supported by an unrestricted grant from Jeff and Judy Buzen to develop personalized perioperative care to ME.

The funders had no role in study design, data collection and analysis, decision to publish, or preparation of the manuscript.
1. Johnson RG, Arozullah AM, Neumayer L, et al.: Multivariable predictors of postoperative respiratory failure after general and vascular surgery: results from the patient safety in surgery study. J Am Coll Surg. 2007; 204(6): 1188-98. PubMed Abstract | Publisher Full Text

2. $\mathrm{F}$ Canet J, Gallart L, Gomar C, et al:: Prediction of postoperative pulmonary complications in a population-based surgical cohort. Anesthesiology. 2010;
113(6): $1338-50$

PubMed Abstract | Publisher Full Text | F1000 Recommendation

3. F Mazo V, Sabaté S, Canet J, et al.: Prospective external validation of a predictive score for postoperative pulmonary complications. Anesthesiology. 2014; 121(2): 219-31.

PubMed Abstract | Publisher Full Text | F1000 Recommendation 
4. F Neto AS, da Costa LGV, Hemmes SNT, et al:: The LAS VEGAS risk score for prediction of postoperative pulmonary complications: An observational study. Eur J Anaesthesiol. 2018; 35(9): 691-701. PubMed Abstract | Publisher Full Text | F1000 Recommendation

5. $\quad \mathrm{F}$ Kim ES, Kim YT, Kang CH, et al.: Prevalence of and risk factors for postoperative pulmonary complications after lung cancer surgery in patients with early-stage COPD. Int J Chron Obstruct Pulmon Dis. 2016; 11: 1317-26. PubMed Abstract | Publisher Full Text | Free Full Text | F1000 Recommendation

6. F Kim M, Brady JE, Li G: Interaction Effects of Acute Kidney Injury, Acute Respiratory Failure, and Sepsis on 30-Day Postoperative Mortality in Patients Undergoing High-Risk Intraabdominal General Surgical Procedures. Anesth Analg. 2015; 121(6): 1536-46. PubMed Abstract | Publisher Full Text | F1000 Recommendation

7. F Bailey JG, Davis PJ, Levy AR, et al:: The impact of adverse events on health care costs for older adults undergoing nonelective abdominal surgery. Can $J$ Surg. 2016; 59(3): 172-9.

PubMed Abstract | Publisher Full Text | Free Full Text | F1000 Recommendation

8. Dimick JB, Chen SL, Taheri PA, et al:: Hospital costs associated with surgica complications: a report from the private-sector National Surgical Quality Improvement Program. J Am Coll Surg. 2004; 199(4): 531-7. PubMed Abstract | Publisher Full Text

9. Rostin P, Teja BJ, Friedrich S, et al:: The association of early postoperative desaturation in the operating theatre with hospital discharge to a skilled nursing or long-term care facility. Anaesthesia. 2019. PubMed Abstract | Publisher Full Text

10. F Fernandez-Bustamante A, Frendl G, Sprung J, et al.: Postoperative Pulmonary Complications, Early Mortality, and Hospital Stay Following Noncardiothoracic Surgery: A Multicenter Study by the Perioperative Research Network Investigators. JAMA Surg. 2017; 152(2): 157-66.

PubMed Abstract | Publisher Full Text | Free Full Text | F1000 Recommendation

11. Kassin MT, Owen RM, Perez SD, et al:: Risk factors for 30-day hospital readmission among general surgery patients. J Am Coll Surg. 2012; 215(3): 322-30.

PubMed Abstract | Publisher Full Text | Free Full Text

12. Mirzakhani $\mathrm{H}$, Williams JN, Mello J, et al.: Muscle weakness predicts pharyngeal dysfunction and symptomatic aspiration in long-term ventilated patients. Anesthesiology. 2013; 119(2): 389-97.

PubMed Abstract | Publisher Full Tex

13. Ruscic KJ, Bøgh Stokholm J, Patlak J, et al:: Supplemental Carbon Dioxide Stabilizes the Upper Airway in Volunteers Anesthetized with Propofol. Anesthesiology. 2018; 129(1): 37-46. PubMed Abstract | Publisher Full Text

14. D'Angelo OM, Diaz-Gil D, Nunn D, et al.: Anesthesia and increased hypercarbic drive impair the coordination between breathing and swallowing Anesthesiology. 2014; 121(6): 1175-83.

PubMed Abstract | Publisher Full Text | Free Full Text

15. White DP: Pathogenesis of obstructive and central sleep apnea. Am J Respir Crit Care Med. 2005; 172(11): 1363-70. PubMed Abstract | Publisher Full Text

16. F Sasaki N, Meyer MJ, Eikermann M: Postoperative respiratory muscle dysfunction: pathophysiology and preventive strategies. Anesthesiology. 2013 118(4): 961-78.

PubMed Abstract | Publisher Full Text | F1000 Recommendation

17. Krodel DJ, Bittner EA, Abdulnour R, et al.: Case scenario: acute postoperative negative pressure pulmonary edema. Anesthesiology. 2010; 113(1): 200-7. PubMed Abstract | Publisher Full Text

18. Rothen HU, Sporre B, Engberg G, et al:: Prevention of atelectasis during general anaesthesia. Lancet. 1995; 345(8962): 1387-91.

PubMed Abstract | Publisher Full Text

19. Slutsky AS, Ranieri VM: Ventilator-induced Lung Injury. N Engl J Med. 2013; 369(22): 2126-36.

PubMed Abstract | Publisher Full Tex

20. Melo MF, Eikermann M: Protect the lungs during abdominal surgery: it may change the postoperative outcome. Anesthesiology. 2013; 118(6): 1254-7. PubMed Abstract | Publisher Full Text

21. Brueckmann B, Villa-Uribe JL, Bateman BT, et al:: Development and validation of a score for prediction of postoperative respiratory complications. Anesthesiology. 2013; 118(6): 1276-85.

PubMed Abstract | Publisher Full Text

22. Mason DP, Subramanian S, Nowicki ER, et al.: Impact of smoking cessation before resection of lung cancer: a Society of Thoracic Surgeons General Thoracic Surgery Database study. Ann Thorac Surg. 2009; 88(2): 362-70; discussion 370-1.

PubMed Abstract | Publisher Full Text

23. F Er Dedekargınoğlu B, Ulubay G, Küpeli E, et al:: Smoking Is Related to Postoperative Pulmonary Complications and Graft Outcomes in Renal Transplant Patients. Exp Clin Transplant. 2016; 14(Suppl 3): 87-90. PubMed Abstract | Publisher Full Text | F1000 Recommendation

24. $\mathrm{F}$ Tagaito $\mathrm{Y}$, Isono $\mathrm{S}$, Tanaka $\mathrm{A}$, et al.: Sitting posture decreases collapsibility of the passive pharynx in anesthetized paralyzed patients with obstructive sleep apnea. Anesthesiology. 2010; 113(4): 812-8.

PubMed Abstract | Publisher Full Text | F1000 Recommendation
25. Zaremba S, Mojica JE, Eikermann M: Perioperative sleep apnea: a real problem or did we invent a new disease? [version 1; referees: 2 approved]. F1000Res. 2016; 5: pii: F1000 Faculty Rev-48.

PubMed Abstract | Publisher Full Text | Free Full Text

26. Amato MB, Barbas CS, Medeiros DM, et al.: Effect of a protective-ventilation strategy on mortality in the acute respiratory distress syndrome. N Engl J Med. 1998; 338(6): 347-54

PubMed Abstract | Publisher Full Text

27. F Acute Respiratory Distress Syndrome Network, Brower RG, Matthay MA, et al:: Ventilation with lower tidal volumes as compared with traditional tidal volumes for acute lung injury and the acute respiratory distress syndrome. $N$ Engl $J$ Med. 2000; 342(18): 1301-8. PubMed Abstract | Publisher Full Text | F1000 Recommendation

28. F Ladha K, Vidal Melo MF, McLean DJ, et al.: Intraoperative protective mechanical ventilation and risk of postoperative respiratory complications: hospital based registry study. BMJ. 2015; 351: h3646.

PubMed Abstract | Publisher Full Text | Free Full Text | F1000 Recommendation

29. de Jong MAC, Ladha KS, Vidal Melo MF, et al:: Differential Effects of Intraoperative Positive End-expiratory Pressure (PEEP) on Respiratory Outcome in Major Abdominal Surgery Versus Craniotomy. Ann Surg. 2016; 264(2): 362-9

PubMed Abstract | Publisher Full Text | Free Full Text

30. F Fuks D, Cauchy F, Ftériche S, et al.: Laparoscopy Decreases Pulmonary Complications in Patients Undergoing Major Liver Resection: A Propensity Score Analysis. Ann Surg. 2016; 263(2): 353-61. PubMed Abstract | Publisher Full Text | F1000 Recommendation

31. Rodgers A, Walker N, Schug S, et al:: Reduction of postoperative mortality and morbidity with epidural or spinal anaesthesia: results from overview of randomised trials. BMJ. 2000; 321(7275): 1493.

PubMed Abstract | Publisher Full Text | Free Full Text

32. Staehr-Rye AK, Meyhoff CS, Scheffenbichler FT, et al.: High intraoperative inspiratory oxygen fraction and risk of major respiratory complications. $\mathrm{Br} \mathrm{J}$ Anaesth. 2017; 119(1): 140-9.

PubMed Abstract | Publisher Full Text

33. Grabitz SD, Farhan HN, Ruscic KJ, et al:: Dose-Dependent Protective Effect of Inhalational Anesthetics Against Postoperative Respiratory Complications: A Prospective Analysis of Data on File From Three Hospitals in New England. Crit Care Med. 2017; 45(1): e30-e39.

PubMed Abstract | Publisher Full Text

34. Berg H, Roed J, Viby-Mogensen J, et al.: Residual neuromuscular block is a risk factor for postoperative pulmonary complications. A prospective, randomised, and blinded study of postoperative pulmonary complications after atracurium, vecuronium and pancuronium. Acta Anaesthesiol Scand. 1997; 41(9): 1095-103. PubMed Abstract | Publisher Full Text

35. F Grosse-Sundrup M, Henneman JP, Sandberg WS, et al:: Intermediate acting non-depolarizing neuromuscular blocking agents and risk of postoperative respiratory complications: prospective propensity score matched cohort study. BMJ. 2012; 345: e6329. study. BMJ. 2012; 345: e6329.
PubMed Abstract | Publisher Full Text | Free Full Text | F1000 Recommendation

36. F McLean DJ, Diaz-Gil D, Farhan HN, et al:: Dose-dependent Association between Intermediate-acting Neuromuscular-blocking Agents and Postoperative Respiratory Complications. Anesthesiology. 2015; 122(6): 1201-13. PubMed Abstract| Publisher Full Text | F1000 Recommendation

37. F Kirmeier E, Eriksson LI, Lewald $\mathrm{H}$, et al:: Post-anaesthesia pulmonary complications after use of muscle relaxants (POPULAR): a multicentre, prospective observational study. Lancet Respir Med. 2019; 7(2): 129-140. PubMed Abstract | Publisher Full Text | F1000 Recommendation

38. $\mathrm{F}$ Shin $\mathrm{CH}$, Long DR, McLean $\mathrm{D}$, et al: : Effects of Intraoperative Fluid Management on Postoperative Outcomes: A Hospital Registry Study. Ann Surg. 2018; 267(6): 1084-92.

PubMed Abstract | Publisher Full Text | F1000 Recommendation

39. Corcoran $\mathrm{T}$, Rhodes JE, Clarke S, et al.: Perioperative fluid management strategies in major surgery: a stratified meta-analysis. Anesth Analg. 2012; 114(3): 640-51.

PubMed Abstract | Publisher Full Text

40. Long DR, Lihn AL, Friedrich S, et al.: Association between intraoperative opioid administration and 30-day readmission: a pre-specified analysis of registry data from a healthcare network in New England. Br J Anaesth. 2018; 120(5): 1090-1102.

PubMled Abstract | Publisher Full Text

41. F Lee LA, Caplan RA, Stephens LS, et al.: Postoperative opioid-induced respiratory depression: a closed claims analysis. Anesthesiology. 2015; 122(3): $659-65$.

PubMed Abstract | Publisher Full Text | F1000 Recommendation

42. F Izrailtyan I, Qiu J, Overdyk FJ, et al.: Risk factors for cardiopulmonary and respiratory arrest in medical and surgical hospital patients on opioid analgesics and sedatives. PLoS One. 2018; 13(3): e0194553. PubMed Abstract | Publisher Full Text | Free Full Text | F1000 Recommendation

43. F Pirrone M, Fisher D, Chipman D, et al:: Recruitment Maneuvers and Positive End-Expiratory Pressure Titration in Morbidly Obese ICU Patients. Crit Care Med. 2016; 44(2): 300-7.

PubMed Abstract | Publisher Full Text | F1000 Recommendation 
44. F Butterly A, Bittner EA, George E, et al.: Postoperative residual curarization from intermediate-acting neuromuscular blocking agents delays recovery room discharge. Br J Anaesth. 2010; 105(3): 304-9.

PubMed Abstract | Publisher Full Text | F1000 Recommendation

45. Grabitz SD, Rajaratnam N, Changani K, et al.: The Effects of Postoperative Residual Neuromuscular Blockade on Hospital Costs and Intensive Care Unit Admission: A Population-Based Cohort Study. Anesth Analg. 2019. PubMed Abstract | Publisher Full Text

46. Checketts MR, Alladi R, Ferguson K, et al:: Recommendations for standards of monitoring during anaesthesia and recovery 2015: Association of Anaesthetists of Great Britain and Ireland. Anaesthesia. 2016; 71(1): 85-93. PubMed Abstract | Publisher Full Text | Free Full Text

47. $\mathrm{F}$ Brueckmann B, Sasaki N, Grobara P, et al:: Effects of sugammadex on incidence of postoperative residual neuromuscular blockade: a randomized, controlled study. Br J Anaesth. 2015; 115(5): 743-51.

PubMed Abstract | Publisher Full Text | F1000 Recommendation
48. F Thacker JK, Mountford WK, Ernst FR, et al:: Perioperative Fluid Utilization Variability and Association With Outcomes: Considerations for Enhanced Recovery Efforts in Sample US Surgical Populations. Ann Surg. 2016; 263(3): 502-10. PubMed Abstract | Publisher Full Text | F1000 Recommendation

49. Groeben $\mathrm{H}$ : Epidural anesthesia and pulmonary function. $J$ Anesth. 2006; 20(4): 290-9.

PubMed Abstract | Publisher Full Text

50. F Schaller SJ, Anstey M, Blobner M, et al.: Early, goal-directed mobilisation in the surgical intensive care unit: a randomised controlled trial. Lancet. 2016 388(10052): 1377-88.

PubMed Abstract | Publisher Full Text | F1000 Recommendation

51. F Taenzer AH, Pyke JB, McGrath SP, et al:: Impact of pulse oximetry surveillance on rescue events and intensive care unit transfers: a before-andafter concurrence study. Anesthesiology. 2010; 112(2): 282-7.

PubMed Abstract | Publisher Full Text | F1000 Recommendation 


\section{Open Peer Review}

\section{Current Peer Review Status:}

\section{Editorial Note on the Review Process}

Faculty Reviews are review articles written by the prestigious Members of Faculty Opinions. The articles are commissioned and peer reviewed before publication to ensure that the final, published version is comprehensive and accessible. The reviewers who approved the final version are listed with their names and affiliations.

\section{The reviewers who approved this article are:}

\section{Version 1}

\section{Mehmet Haberal}

Division of Transplantation, Department of General Surgery, Baskent University Faculty of Medicine, Ankara, Turkey Competing Interests: No competing interests were disclosed.

\section{Albert Dahan (iD)}

Department of Anesthesiology, Leiden University Medical Center, Leiden, The Netherlands Competing Interests: No competing interests were disclosed.

The benefits of publishing with F1000Research:

- Your article is published within days, with no editorial bias

- You can publish traditional articles, null/negative results, case reports, data notes and more

- The peer review process is transparent and collaborative

- Your article is indexed in PubMed after passing peer review

- Dedicated customer support at every stage

For pre-submission enquiries, contact research@f1000.com 